\title{
Reaching beyond: Blogging a digital autobiographical practical theology
}

\author{
Author: \\ Jan Albert van den Berg ${ }^{1}$ \\ Affiliation: \\ ${ }^{1}$ Department of Practical \\ Theology, University of the \\ Free State, South Africa \\ Correspondence to: \\ Jan Albert van den Berg \\ Email: \\ vdbergja@ufs.ac.za \\ Postal address: \\ PO Box 100985, Brandhof \\ 9324, South Africa

\section{Dates:} \\ Received: 30 May 2013 \\ Accepted: 06 Sept. 2013 \\ Published: 06 Aug. 2014 \\ How to cite this article: \\ Van den Berg, J.A., 2014, \\ 'Reaching beyond: Blogging \\ a digital autobiographical \\ practical theology', Verbum \\ et Ecclesia 35(2), Art. \#873, \\ 6 pages. http://dx.doi. \\ org/10.4102/ve.v35i2.873

\section{Copyright:} \\ (C) 2014. The Authors. \\ Licensee: AOSIS \\ OpenJournals. This work \\ is licensed under the \\ Creative Commons \\ Attribution License.
}

Against the backdrop of a virtual existence, this contribution has portrayed the intimate relationship between two practical theologians. Through the use of biographical accounts, the author has not only attempted to indicate the significant contribution of Professor Julian Müller to the field of practical theology, but has also described the influence of this work on his own life and current research practice. In these descriptions of engagement, on the basis of which relevant research accents have been demarcated, a scenario pointing towards relevant future developments has also been indicated. In the mapping of a digital autobiographical practical theology, the author has personally 'reached beyond' in his endeavour to identify new research avenues in the articulation of the autobiographical language of a lived digital religion.

\section{Introduction}

A weblog (also referred to as a blog) is a special kind of Internet website consisting of consecutive dated entries (like a logbook) ... The entries are often referred to as posts or postings ... The activity of writing a weblog is called blogging and weblogs are now a mainstream tool of journalists, politicians and many ordinary individuals who write about their hobbies, education, interests or personal lives. The collective world of weblog writers (also called bloggers) and their weblogs often goes by the name of the blogosphere. It is an important new tool of self-expression and social communication. (Potgieter 2012:26)

In taking up the challenge to formulate a portrayal, in a specially dedicated academic article, of a personal association with Professor Julian Müller that has extended over a period of more than two decades, I have chosen to use imaginary blog postings as a central metaphor. It is important to emphasise that the metaphor of 'imaginary blog postings' is not aimed at describing a new research methodology. Rather, it offers a metaphorical understanding on the basis of which the article is structured in terms of its content and formal presentation. This choice of a metaphor is supported and motivated on at least three levels. Firstly, owing to the prosaic character that is normally associated with blogs, this image fits easily into the broad, narratively informed research framework that is prominent in the work of Professor Müller, and within which I also define my own placement with regard to the positioning of my work. Secondly, web journals, as blogs are also called, exhibit a strongly autobiographical character; and for this very reason, this medium would be eminently suitable, through the use of imaginary blog entries (imagination represents an important development and dimension in narrative activity), for reflecting on the authentic and solid personal dimensions of the academic relationship between Professor Müller and myself. (The personal nature of this relationship can be discerned in, inter alia, the various ways in which reference is made to Professor Julian Müller in the article.) Thirdly, the use of the 'blog' metaphor places the research within the domain of the digital world, with the result that it can readily serve as the background on the basis of which the article is structured. These entries - as in the case of most blog postings on the Internet - are provisional in character and are thus not meant to be regarded as a final reflection, but rather as a contribution to the continuation of the discourse. Precisely for this reason, with a view to describing the dynamics involved in the research process, a purposeful decision has been made to use the verb 'blogging' in the imperfect (and thus 'incomplete') present tense.

A blog is usually compiled in reverse chronological order, with the most recent entry appearing first. Bearing this chronology in mind, I follow the tracks made by recent important contributions in the work of Professor Müller, as reflected in his description of the relationship between autobiography and theology as life theology (Müller 2011a:1-2). In the description hereof, I have deliberately chosen the metaphor of 'tracing', following Ganzevoort's (2009) threefold understanding of the practical theological activity of 'tracing', which he elucidates as follows:

The first is the archaic meaning of traversing or travelling over a certain area. The second involves meanings like following or tracking the footprints of someone or something, like when on a hunt. Metaphorically, it 
can be transposed to studying something in detail, like the history of an idea, the whereabouts of money moving around the world, or one's ancestry. It may also refer to the search for traces, signs, evidence, or remains of something that indicate a certain activity or presence. Tracing then has to with reconstructing and developing knowledge. The last type of meaning has to do with drawing or sketching. It may be the careful forming of letters or figures or even certain kinds of decoration, but usually it is a form of copying by hand through a transparent sheet. Here tracing has to do with constructing, modelled after an external reality. (p. 5)

The embodiment of the content of 'tracing' - the journey across a domain (or domains) of life and/or the search for, and subsequent following of, footprints in the quest for an own route - finds resonance in my own 'blogging' activity. Thus, it is precisely in this 'blogging' or 'tracing' that the dynamic process of the 'biografisering van het leven' (Ganzevoort 2007:50) takes place. An orientation - and even a re-orientation - towards identity thereby occurs on a variety of levels and in a variety of relationships. Naturally, such blog entries display a strongly narrative character - ranging from fragments derived from own-life texts to excerpts from a novel - with a view to expressing a personal narrative (or narratives), but also as a contribution to the process of 'life writing' (Babbie \& Mouton 1998:502). In order to give clear expression to this objective, I will make use of an italic letter-type, with an indented paragraph format, whenever a fragment of an own-life narrative is being presented:

\begin{abstract}
I vividly remember how, as a new arrival in the world of independent academic writing, I received my first attempt at independent academic writing back from my study supervisor, Professor Julian Müller. A personal discussion followed as I held the first chapter, with relevant comments, in my hand. At the top of the first page of the chapter, I clearly remember, remarks had been written in Julian's flowing handwriting, in pencil. In turning the pages of the chapter, I noticed that he had made various comments in pencil in the text of the chapter. This was the method that he used for my BD thesis, and later also my $M D i v$ thesis, as well as during my PhD research. Thinking back about this now, I can see - metaphorically speaking - a relationship in these pencilled notes, in which he demonstrated respect for my text, which was typed in dark black letters, by writing his comments in light pencil strokes.
\end{abstract}

Linking up with the metaphor of 'blogging', I have also used a second, supporting metaphor, in order to further structure the article: the term 'screenshot' indicates that a dynamic image is digitally captured on a computer screen. This metaphor can be used, for example, as a static image of a specific webpage. The assumption here is that, even though the image is static, it serves as a point of interception for a dynamic development that indeed goes much deeper than meets the eye. In the structuring of the article, the use of different 'screenshots' indicates that a much more dynamic background process underlies the concerned blog than can be portrayed in words. This dynamic substructure cannot be fully captured, however, owing to limitations pertaining to words and text; but it does challenge the reader to adopt an orientation aimed at 'reaching beyond'.

\section{Blog post 1 \\ Reaching beyond: A screenshot of the 'opening up' of the horizon}

In Ettienne van Heerden's (2009:190) acclaimed novel, 30 Nagte in Amsterdam [30 nights in Amsterdam], the main character, Henk de Melker, asks a question regarding the special ability of individuals who have the capacity to 'open up the horizon' by looking at it in a certain way. This proverbial opening up of horizons is central to new academic research. In his recent article, 'Practical theology as part of the landscape of social sciences and humanities - A transversal perspective', Julian Müller (2013) poses the following challenge in order to make it possible to facilitate the opening up of new horizons by looking at them in a particular way:

Our goal should rather be to open up the boundaries between practical theology, human, social and even natural sciences. In doing so, we can enrich and broaden our sensitivity towards the human condition and human society as well as the religious community. (p. 5)

In the presentation of provisional perspectives in this article, I have endeavoured, precisely, to examine the horizon(s) of human existence through various lenses, in terms of a practical theological awareness. My objective is to make a contribution to a practical theological research agenda by means of this act of 'looking', or rather - possibly - 'tracing', with a view to the future. A possible modus operandi that could be followed for the envisaged research practice has already been mapped out during the past few years by means of important and direction-giving perspectives by Müller, in the development of a 'postfoundational practical theology'. In the development of such a postfoundational practical theology, in which Müller displays a strong affinity with the theologian of Princeton, Wentzel van Huyssteen, reflections on concrete and contextual realities are described as follows: 'This way of thinking is always concrete, local, and contextual, but at the same time reaches beyond local contexts to transdisciplinary concerns' (Müller 2009:205). Müller's development of this new lens in the tracing of a practical theological understanding and involvement has already received international recognition as an example of a theology of solidarity (Newlands 2006). Arising from the development of this new methodological lens, the accessing of and involvement with a diversity of concrete contexts on the basis of a postfoundational practical theology has also already been comprehensively described and documented. Thus, for example, the impact of the HIV and/or Aids pandemic within the concrete and local context of migratory workers in the fruit industry of the Overberg area in the Western Cape has been described in practical theological terms (August \& Müller 2011).

In my own quest for an understanding of the meaning of a postfoundational practical theology and the implications thereof, I have always been struck by the concept of 'reach [ing] beyond local contexts' (Müller 2009:205). My interpretation of this phrase is that, in the patterns that can be distinguished 
on the basis of my involvement with the concrete and the contextual, I might possibly find accents that would offer clues for the interpretation of other domains of meaning. I would also like to add a second interpretation, in which the words 'reaching' and 'beyond' introduce additional accents of effort(s) involving an ongoing quest for domains that extend further and deeper than might be suspected at first glance.

Central to these academic accents is the quest for congruency - a quest that runs through the life and work of Julian Müller like a golden thread (trail?). In his 2009 autobiographical work, Om te mag twyfel [Having the freedom to doubt], Müller puts it this way: 'I believe that theology is always anchored in a specific personal, social and cultural context' (cf. Müller 2011b:8). If one goes back along the trail of most of Müller's work, and searches with a trained eye, one finds numerous signs of this autobiographical theology in his documentation - or journalisation - of an own life journey. Accents pertaining to an own family of origin, the dynamics of an own family, as well as a life lived in South Africa, repeatedly serve as points of reference in the rubrication of a life inventory that is mapped in such a way that it also acquires a character of 'reaching beyond'. In this way, Müller succeeds in guiding the reader towards the discovery that sometimes that which is most personal can be of great significance for the lives of others. The memory of my first intimate personal contact with Professor Müller is illustrative of this:

One day, as part of an assignment during my fifth year of theological studies (1993), I went to Professor Müller to discuss a graphic portrayal of my family of origin (genogram). During this discussion, he helped me to discover themes from an orientation aimed at 'reaching beyond'. This orientation was not only characteristic of a deeper reflection about myself that ensued as a result thereof; it also played a decisive role in respect of my further studies, and was reflected in my BD thesis and, in the course of time, also in my PhD. In the light of the foregoing, it is not surprising that, in due course, I came to be on first-name terms with Julian. What I had originally only understood as theoretical concepts that were presented by a lecturer, had become the life-changing accents of a friend.

\section{Blog post 2 \\ A screenshot of a memory of the future}

As is often the case with students who are considering a possible theme for a first thesis, I approached Professor Müller during that period with a great amount of naïve enthusiasm - with a particular suggestion for a research theme. After chatting to me in a relaxed manner about my proposed theme, he also mentioned other possibilities. He pointed out that these alternatives had the potential to be further developed in Masters and Doctoral research. To this day, I have always been grateful for his farsightedness. In this way, Julian helped me to learn to make a decision with the future in mind. This not only helped to determine the nature of my first BD thesis, but also mapped out the trajectory of my further postgraduate studies. The passing of time brought yet more confirmation that the decisions of today do, indeed, unlock specific possibilities for tomorrow.

In my opinion, such an attunement and sensitivity to whatever tomorrow may hold is well encompassed in the concept of a 'memory of the future'. This notion, which is central to the scientific field of futures studies, has already been defined by several persons (Adam 2004; De Geus 1997; Ingvar 1985). Recently, Lombardo (2008:2) described this awareness of the future as a 'future consciousness' or:

the human capacity to be conscious of the future, to create ideas, images, goals, and plans about the future, to think about these mental creations and use them in directing one's action and one's life. (p. 2)

What is thus of importance is that the orientation towards the future plays a guiding role in my present decisions and behaviour. In the presentation of these perspectives, a biographical (or autobiographical) exploration thereof implies that I am tracing the accents of these theoretical concepts in the lives of others, as well as in my own.

Julian Müller was, and is, pre-eminently a prophet, who, with a keen eye, has assisted, and still assists people to perceive transitions, but also turning points. The pointing out of transitions has already been documented by Müller in a variety of scientific and other publications. Müller himself relates how various academic transitions have been discernible in his own life: from perspectives for an ecohermeneutic model to narrative therapy and, ultimately, the development of a postfoundational practical theology, with a strong emphasis on interdisciplinary reflections arising from a transversal rationality (Müller 2011c:1-2). With a keen sensitivity for the fibrillation of the minds of postmodern human beings, he has also assisted with the description of transitions in publications dealing with religious faith (Müller 2011b). In my opinion, one of the reasons why Müller has been able to succeed in opening up the future by looking at it in a certain way is that, in the acknowledgement of his own autobiographical accents, he has brought about the realisation of a quest to 'reach beyond'. In taking account of his own reality, he has had the insight to transpose these perspectives in such a way that they hold meaning, not only for the present, but indeed also for the future. In his article, 'Postfoundational practical theology for a time of transition', he writes as follows: '... there seems to be consensus about the fact that there was, is, a turning point, that we are living in a time of transition' (Müller 2011c:1). In his latest book, The future, the former American vice-president, Al Gore (2013), dramatically confirms this factor, in his observation that there is currently a general consensus that:

... the future now emerging will be extremely different from anything we have ever known in the past. It is a difference not of degree but of kind. There is no prior period of change that remotely resembles what humanity is about to experience. (n.p.)

In my own quest to open up the horizon of the future by looking at it in a certain way, I completed a Masters programme in Futures Studies (the only one of its kind in Africa) in 2010, which is housed in the Management School of the University of Stellenbosch. In the facilitation of a memory of the future, over the course of time, I have been further developing a life-orientation that gives due acknowledgement to the fact that the realisation of the future demands active participation. For me, reflections on a sustainable future represent a practice in which the meaning of involvement in a local and concrete reality can be transcribed into a mode of 'reaching beyond'. In this regard, I 
actively seek possibilities that can positively influence the realisation of tomorrow, and of a time beyond tomorrow.

In giving shape to a memory of the future, it is of cardinal importance to engage in a scanning of the environment, in search of specks on the horizon that may possibly lead to change. A good illustration of such accountable scanning of the future is the authoritative 'State of the Future' report of the well-known Millennium Project of the United Nations, in which it is pointed out that the impact of technological development currently comprises one of the most important challenges for a sustainable future (Glenn, Gordon \& Florescu 2012). Bearing this factor in mind, it is understandable that, if a specific contribution to the future is made, in which technological development, inter alia, is an important driver, the tracing of the meaning thereof should enjoy high priority. Taking account of the concrete, contextual and local accents encountered in a postfoundational practical theology, the countrywide, but also worldwide growth in mobile communication technology can be mentioned as an example. This 'fluid' world (Bauman 2007), created by various evolutionary stages of Internet development and embodied, for example, in the growth of the cellphone market as a worldwide phenomenon (Time 2012), provides a vivid reflection of this reality. Sweet (2012) has therefore rightfully commented that 'The cell is your covenant with life; the cell is your convent in life'; leading to the given factor that the transformational mobile device is currently at the centre of human existence.

\section{Blog post 3}

\section{A screenshot of practical theological alternatives in the web of life}

Transitions and turning points - which often also become watershed moments - can frequently be discerned in the domain of an own life. In my view, in the tracing of autobiographical perspectives, a keen eye is needed, in order to perceive signs of such transitions and turning points:

It was during my doctoral research that I was exposed to the digital world for the first time. Initially, I was astounded at the medium offered by the test board of a computer, which firstly allowed black letters to appear on the white screen of the computer - after which these words could immediately be printed on white paper. During this period, electronic communication also arrived on the scene; and I vividly remember how, after formulating an email to Julian, I was always amazed at how quickly I received his digitally formulated reply. To this day, I still think that he is one of those persons who handle their email communications in the best and fastest possible manner. Later on, I was thrilled at the prospect of visiting Julian's own webpage and of being able to read a variety of articles, popular contributions and sermons in a digital format. There was even a link that could be used by interested persons who wished to participate in discussions on pastoral therapy with Julian per email.

In the description of this experience, a specific practical theological orientation is presupposed. Practical theology also displays a development that extends from an initial orientation towards the ecclesiastical praxis, to the most recent accents falling on the importance and relevance of the public domain. This reality is acknowledged in one of the central metaphors associated with the study of practical theology, namely 'the web of life' (Miller-McLemore 2012; Osmer 2008) - in which, ironically enough, the contributory role and influence of technological development is acknowledged. In this regard, Miller-McLemore (2012) writes:

If one believes in the interconnection and interdependence of all life, a premise behind the general idea of the web itself, then one knows that it is highly likely that our use of the term was shaped, at least indirectly, by the incredible technological developments hovering in the background, soon to become a dominant foreground. (n.p.)

However, I am of the opinion that we are currently entering the era - if we have not entered it already - in which technological development has begun to take over the 'dominant foreground'. Proceeding from the assumption that practical theology entails the study of practices of 'lived religion' - including the practices of the future - the importance of interdisciplinary reflection is taken as a given factor. A possible practical theological description of, and contribution to, this challenge can be found, in my opinion, in an interdisciplinary method of research - for example, that of transversal rationality, which places emphasis on contextual realities, in such a way that a contribution can be made to a larger discourse (Müller 2009).

In turn, this orientation towards a particular modus operandi indeed facilitates practical theological alternatives (Müller 2011c) in which the horizons of understanding and practice are broadened:

We must rather open up the boundaries between theology and disciplines within social sciences, humanities and natural sciences. In doing this, we can deepen and broaden the sensitivity for the human condition within human society and religious community. The contribution of Practical Theology in this interdisciplinary process is to strengthen the sensitivity for the human condition and human community, also in terms of the community of faith. (p. 5)

The aim of this contribution is, precisely, to engage in an earnest consideration of the extent and influence of the continual deluge of digital content and communication. I would therefore like to conduct an investigation in the context of a growing research practice. The objective in this regard would be to determine how practical theology could render a unique contribution in the accommodation of the discourse with futures studies, inter alia. In the mapping of this transversal discourse with non-traditional dialogue partners from the economic and management sciences, a relevant contribution will be made to a developing practice. In this contribution, a perspective that entails the dynamics of 'reaching beyond' will not only be accommodated, but also accentuated.

\section{Blog post 4}

\section{A screenshot of real life in digital format: Blogging a digital (auto)biographical practical theology}

Part of the privilege of being a postgraduate student under Julian's leadership was reflected in the regular discussions of films that were 
held as part of the structured postgraduate meetings. I remember how, during these discussions, I developed a keen eye for, and sensitivity towards the visual impact and the meanings that are conveyed through the medium of films. A specific concrete, local and contextual message, with dimensions of 'reaching beyond', is portrayed in a narratively informed manner in films. I remember how, together with other members of the group of postgraduate students of which I was a part, I watched the following films: in the New Zealand movie, Once were warriors (1994), a powerful message on family violence is conveyed. In the film, Ill Postino (1994), with a theme relating to the arts, the metaphorical world of the Chilean poet, Pablo Neruda, is sketched; whilst in the South African film, Yesterday (2004), the viewer is challenged to reflect on the destructive outcome of HIV and/or Aids. Years later, being thoroughly aware of the influence of the Facebook phenomenon, I watched the award-winning film, The social network (2010). The origin, development and far-reaching consequences of Mark Zuckerberg's Facebook are illustrated in this film. One of the characters, Sean Parker, refers to the Facebook phenomenon as 'the true digitalization of real life' (The Niles Files 2011:2). Not long thereafter, the world-famous Internet psychologist and philosopher, Sherry Turkle (2011:n.p.), pointed out in her book, Alone together, that what is becoming visible in the growing virtual environment is nothing other 'than the future unfolding'. For this very reason, in the blogging of a digital autobiographical practical theology, I aim to seek out personal accents in the meaning of a growing virtual world. Being a mere proverbial drop in the ocean of the digital world, my own presence in that world is limited to the use of the email facility - and a Facebook and a Twitter account, both of which are kept in operation by means of a few sporadic entries here and there. Ironically enough, and despite the format of this article, I am currently not operating an active blog. Bearing important statistical indicators in mind, as well as my own sensitivity towards the future, it would seem to be a given factor that this digital reality is breaking open a new horizon of understanding in relation to human life, with concomitant new challenges. Personally, this means that I should evaluate my own presence in the digital world according to its meaning and relevance. This challenge of reflection may lead me to once again consider entering into a new and meaningful involvement with digital reality.

Even in the traditional field of religious studies alone, it seems that important new accents are being mapped out. In her latest book, Digital religion. Understanding religious practice in new media worlds, Heidi Campbell (2013) points out some important dimensions of 'digital religion', as follows:

... when lived religious practice and digital culture meet, a 'third space' emerges, a hybridized and fluid context requiring new logics and evoking unique forms of meaning-making. Digital religion as a concept acknowledges not only how the unique character of digital technology and culture shapes religious practice and beliefs, but also how religions seek to culture new media contexts with established ways of being and convictions about the nature of reality and the larger world. (n.p.)

On the basis of my awareness of, and quest for, 'convictions about the nature of reality and the larger world' (Campbell 2013:n.p.), I am of the opinion that it has become a matter of priority to reflect, within the context of a digital autobiographical practical theology, on a possible expansion of Ruard Ganzevoort's (2009) original description of a 'lived religion' to that of a 'lived digital religion'. In the development and description of aspects of a lived digital religion, I am convinced that 'life on the screen' cannot take place without the discursive agenda of a postfoundational practical theology.

Without any empirical research being presented in this article, the sheer quantity of available spaces offered by alreadyexisting themes and studies is overwhelming. Pressing the proverbial 'Refresh' button on the webpage means that some of the following themes - to mention just a few - should continually be loaded afresh: on a macro-level, practical theological research should display a sensitivity towards the meaning of the social Web 2.0 and the embodiment thereof in social media (Lesame, Sindane \& Potgieter 2012:6). Ironically enough, various signs of the future can already be seen on the horizon, pointing to the so-called development of the Web 3.0, or the 'semantic' or 'intelligent' web (Glenn et al. 2012:31). It would seem that this evolutionary development on the horizon will permanently change the cartography of the existence of human beings. It is precisely within this space (or these spaces) that the following themes of a more personal character - to mention just a few - make their appearance within the scanning of a future reality: the impact of artificial intelligence in an age of singularity (Kurzweil 2010), as well as the influence of the digital world in the developing field of digital games, or 'gaming' (Reeves \& Read 2009), in which a new orientation in terms of time, attention and focus is mapped out. An important indication of relevant pastoral challenges of this new digital reality can for example already be found in the indication of Internet gaming in the recently released fifth edition of the Diagnostic and statistical manual of mental disorders (DSM-V) with the following aim: 'By listing Internet Gaming Disorder in DSM'5 Section III, APA hopes to encourage research to determine whether the condition should be added to the manual as a disorder' (American Psychiatric Association 2013).

\begin{abstract}
In his book, You're not a gadget (2011:4), Lanier writes: 'Technologies are extensions of ourselves ... our identities can be shifted by the quirks of gadgets. It is impossible to work with information technology without also engaging in social engineering'. In this initial typing out of the first letters and words of my own 'digital autobiographical practical theology', with a view to the future, and in the process of nurturing an active memory of the future, I am sensitive to this warning. What is the particular nature of the challenge that is facing me - namely, that of making a contribution to the process of 'social engineering' in an accountable manner, as a practical theologian, by means of the insights gleaned from futures studies and information technology, inter alia? Regarding the identification of a central theme within the context of this research challenge, Van der Westhuizen (2010:n.p.), as a postgraduate student of Julian Müller, offers the following description of the practical theologian's work: 'We listen for the transformative nature of God's work and how this is present in stories. We are generally concerned about spirituality and systems of religion and, as such, we would want to listen to how these are integrated into people's stories and how God is experienced in a particular situation'.
\end{abstract}

\section{Conclusion}

Naturally, these comments merely amount to a provisional blog posting (or postings) of my own personal digital autobiographical perspectives which call for a response that 
is illustrative of the reflexive dialogical character of a digital world. The character and nature of a digital autobiographical theology is thereby portrayed in such a way that life and identity are understood to be connected, in the broadest possible sense, in a non-static, but always dynamic manner (Müller 2011a). In the interactive nature of this digital world, dynamic reflection is presupposed, which acknowledges what is most personal, and in which a continual quest is conducted for perspectives that 'reach beyond'. For this very reason, as pointed out by Müller (2011a) himself, the purpose of a Festschrift is, precisely, to facilitate reflection on the trajectory of a biography, in order to open up new vistas. All of these aspects are central to the significant contribution that is to be found in the life and work of Professor Julian Müller as lecturer, mentor, friend and colleague.

\section{Acknowledgements Competing interests}

The author declares that he has no financial or personal relationships that may have inappropriately influenced him in writing this article.

\section{References}

Adam, B., 2004, 'Memory of futures', KronoScope 4(2), 297-315. http://dx.doi. org/10.1163/1568524042801392

August, A. \& Müller, J.C., 2011, 'HIV and/or AIDS, migrant labour and the experience of God: A practical theological postfoundationalist approach', HTS Teologiese Studies/Theological Studies 67(3), Art. \#774, 6 pages. http://dx.doi.org/10.4102/ hts.v67i3.774

Babbie, E. \& Mouton, J., 1998, The practice of social research, Oxford University Press, Cape Town.

Bauman, Z., 2007, Liquid Times. Living in Age of Uncertainty, Polity Press, Cambridge.

Campbell, H.A., 2013, Digital religion: Understanding religious practice in new media worlds, Routledge, London. (Kindle edition).

De Geus, A., 1997, The living company. Growth, learning and longevity in business, Nicholas Brealey Publishing, London.

American Psychiatric Association, 2013, DSM-V - Internet gaming disorder, viewed 23 May 2013, from http://www.dsm5.org/Documents/Internet\%20Gaming\%20 Disorder\%20Fact\%20Sheet.pdf

Ganzevoort, R.R., 2007, 'Waarheen met de praktische theologie?', Thelogische Debat $4(1), 20-24$.

Ganzevoort, R.R., 2009, 'Forks in the road when tracing the sacred. Practical theology as hermeneutics of lived religion', Presidential address to the ninth conference of the International Academy of Practical Theology, Chicago, 03 August, viewed 24 April 2010, from http://www.ruardganzevoort.nl/pdf/2009_Presidential.pdf

Glenn, J.C., Gordon, T.J. \& Florescu, E., 2012, State of the future, The Millennium Project. World Federation of UN Associations, Washington, DC.
Gore, A., 2013, The future, W.H. Allen, London. (Kindle edition).

III Postino, 1994, II Postino: The postman, viewed 24 April 2013, from http://www. rottentomatoes.com/m/il_postino_the_postman

Ingvar, D.H., 1985, 'Memory of the future. An essay on the temporal organization of conscious awareness', Human Neurobiology 4(3), 127-136. PMid:3905726

Kurzweil, R., 2010, The singularity is near, Gerald Duckworth, London. (Kindle edition). Lanier, J., 2011, You are not a gadget, Vintage Books, New York.

Lesame, Z., Sindane, S. \& Potgieter, P., 2012, 'New media: Theories and applications', in Z. Lesame, B. Mbatha \& S. Sindane (eds.), New media in the information society, pp. 1-21, Van Schaik Publishers, Pretoria.

Lombardo, T., 2008, The evolution of future consciousness, Authorhouse, Bloomington. Miller-McLemore, B.J., 2012, Christian theology in practice: Discovering a discipline, William B. Eerdmans, Grand Rapids. (Kindle edition).

Müller, J.C., 2009, 'Transversal rationality as a practical way of doing interdisciplinary work, with HIV and Aids as a case study', Practical Theology in South Africa 24(2), 199-228.

Müller, J.C., 2011a, '(Outo)biografie as teologie', HTS Teologiese Studies/ Theological Studies 67(3), Art. \#1113, 5 pages. http://dx.doi.org/10.4102/hts.v67i3.1113

Müller, J.C., 2011b, Om te mag twyfel. 'n Gelowige se reis, Tafelberg, Cape Town.

Müller, J.C., 2011c, 'Postfoundational practical theology for a time of transition', HTS Teologiese Studies/Theological Studies 67(1), Art. \#837, 5 pages. doi.10.4102/hts. v67i1.837

Müller, J.C., 2013, 'Practical theology as part of the landscape of social sciences and humanities - A transversal perspective', HTS Teologiese Studies/ Theological Studies 69(2), Art. \#1299, 5 pages. http://dx.doi.org/10.4102/hts.v69i2.1299

Newlands, G., 2006, 'Public theology in postfoundational tradition', in F. LeRon Shults (ed.), The evolution of rationality, pp. 394-417, William B. Eerdmans, Cambridge.

The Niles Files, 2011, Revolutions and revelations: The Oscars for 1967 and 2010 viewed 23 May 2011, from http://nilesfilmfiles.blogspot.com/2011/02/ revolutions-and-revelations-oscars-for.html

Once Were Warriors, 1994, viewed 30 April 2013, from http://www.rottentomatoes. $\mathrm{com} / \mathrm{m} /$ once were warriors

Osmer, R., 2008, Practical theology: An introduction, William B. Eerdmans, Grand Rapids.

Potgieter, P., 2012, 'An overview of online new media', in Z. Lesame, B. Mbatha \& S. Sindane (eds.), New media in the information society, pp. 23-35, Van Schaik Publishers, Pretoria.

Reeves, B. \& Read, J.L., 2009, Total engagement: Using games and virtual worlds to change the way people work and businesses compete, Harvard Business Press, Boston.

Sweet, L., 2012, Viral. How social networking is poised to ignite revival, Waterbrook Press, Colorado Springs. (Kindle edition).

Time, 2012, The wireless issue. 10 Ways your phone is changing the world, 27 August, 21-51.

The social network, 2010, viewed 22 April 2013, from http://www.imdb.com/title/ tt1285016

Turkle, S., 2011, Alone together: Why we expect more from technology and less from each other, Basic Books, New York. (Kindle edition).

Van der Westhuizen, Z., 2010, 'Transversality and interdisciplinary discussion in postfoundational practical theology - Reflecting on Julian Müller's interdisciplinary guidelines', HTS Teologiese Studies/Theological Studies 66(2), Art. \#910, 5 pages. http://dx.doi.org/10.4102/hts.v66i2.910

Van Heerden, E., 2009, 30 Nagte in Amsterdam, Tafelberg Uitgewers, Cape Town.

Yesterday, 2004, viewed 01 May 2013, from http://www.rottentomatoes.com/ $\mathrm{m} / 1153321$-yesterday 